ESTUDIOS $\lambda$ AMBDA.

Teoría y práctica de la didáctica

en lengua y literatura

\title{
RWR: the reading-writing-research tasks for thesis writing development
}

\author{
(LEI: Tareas de Lectura, Escritura e Investigación para el \\ desarrollo de la escritura de tesis)
}

\begin{abstract}
Vicky Ariza-Pinzón iD , Benemérita Universidad Autónoma de Puebla, Puebla, México Elba MÉndez-GARCÍA iD , Benemérita Universidad Autónoma de Puebla, Puebla, México Georgina Aguilar-GonzÁlez iD , Benemérita Universidad Autónoma de Puebla, Puebla, México
\end{abstract}

\author{
Volumen 4, Número 2 \\ Julio - diciembre de 2019 \\ p. $48-70$
}

Este número se publicó el 23 de agosto de 2019

Artículo recibido: 4 de septiembre de 2018

Artículo aceptado para publicación: 23 de agosto de 2019

ISSN: 2448-5942, doi: https://doi.org/10.36799/el.v4i2.100

Citar este artículo como:

Ariza Pinzón, V., Méndez García, E., y Aguilar González, G. (2019). RWR: the reading-writing-research tasks for

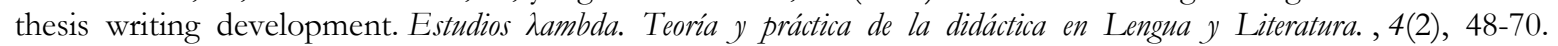
https://doi.org/10.36799/el.v4i2.100

Derechos de autor: El autor o autores conservan en todo momento sus derechos morales y patrimoniales sobre la obra; la obra no se puede alterar, transformar o ampliar; siempre debe reconocerse la autoría del documento referido. Ninguna de las modalidades de los documentos publicados en Estudios Aambda. Teoría y práctica de la didáctica en lengua y literatura tienen fines comerciales de naturaleza alguna.

Los contenidos de este artículo están bajo una licencia de Creative Commons Atribución No Comercial- Sin Derivadas 4.0 Internacional cc) (i) 


\title{
RWR: the reading-writing-research tasks for thesis writing development
}

\author{
(LEI: Tareas de Lectura, Escritura e Investigación para el \\ desarrollo de la escritura de tesis)
}

\author{
VICKY ARIZA-PINZÓN ${ }^{1}$ \\ ELBA MÉNDEZ-GARCÍA ${ }^{2}$ \\ GEORGINA AgUILAR-GONZÁLEZ ${ }^{3}$
}

\begin{abstract}
RESUMEN
La alfabetización del investigador representa un reto para la escritura de tesis a nivel universitario. Una posible explicación para este reto puede surgir a partir de la interacción de varios procesos sociales, mismos que en muchos casos no son evidentes para el escritor de tesis incipiente. Frecuentemente, el énfasis reside en la escritura; lo cual deja de lado procesos de lectura e investigación (Paltridge, Harbon, Hirsh, Shen, Stevenson, Phakiti y Woodrow, 2009, 22). Además, es posible que en el trabajo de supervisión de tesis, el proceso de alfabetización del investigador no sea claramente descrito en el quehacer de leer, escribir y llevar a cabo la investigación. Desde una perspectiva cualitativa, este trabajo analiza las transcripciones de un grupo focal con estudiantes, escritores de tesis, del programa de Licenciatura en la enseñanza del inglés en una universidad del centro de México. Los objetivos de la investigación son (1) identificar las tareas que acompañan a la escritura de tesis a nivel universitario y (2) explorar como estas tareas trabajan para la construcción del texto académico. Resultados preliminares confirman que las tareas de lectura y escritura son inherentes al desarrollo del texto académico, por ello les nombramos tareas de Lectura, Escritura e Investigación (tareas L-E-I). Sin embargo, es de resaltar que esta interacción de prácticas sociales no es evidente mientras se escribe una tesis. Las tareas son percibidas por escritores y supervisores como procesos independientes, lo cual puede obstruir la conclusión del texto escrito. Esta visión segmentada también obstruye el desarrollo de la literacidad investigativa. El presente trabajo, puede tener implicaciones para realizar una supervisión y asignación de tareas de manera explícita.
\end{abstract}

PALABRAS CLAVE: tareas de literacidad, escritura académica, tareas de investigación, integración conceptual

\begin{abstract}
Becoming research literate represents a challenge for thesis writing at tertiary level. One possible reason for this challenge results from the many interacting social processes involved in thesis writing, which may not be so evident for novice thesis writers. Frequently, the emphasis is given to writing; leaving aside the reading and research processes (Paltridge, Harbon, Hirsh, Shen, Stevenson, Phakiti and Woodrow, 2009, 22). Moreover, teachers who supervise students' work may not be able to clearly describe how students become research literate as they read, write and carry out research. Following a qualitative tradition, this paper analyzes transcriptions from a focus group with students who were in the process of writing thesis for an undergraduate ELT program in Central Mexico. The main objectives of this research are (1) to

\footnotetext{
${ }^{1}$ Mtra. Vicky Ariza Pinzón. Maestría en la Enseñanza del Inglés por la Benemérita Universidad Autónoma de Puebla. Docente de tiempo completo en la Facultad de Lenguas, BUAP. México, Puebla. vicky.ariza@,correo.buap.mx ORCID: https://orcid.org/0000-0003-4544-4708

${ }^{2}$ Mtra. Elba Méndez García. Maestría en la Enseñanza del Inglés por la Benemérita Universidad Autónoma de Puebla. Docente de tiempo completo en la Facultad de Lenguas, BUAP. México, Puebla. elba.mendez@,correo.buap.mx ORCID: https://orcid.org/0000-0001-8816-5130

${ }^{3}$ Mtra. Georgina Aguilar González. Maestría en la Enseñanza del Inglés por la Benemérita Universidad Autónoma de Puebla. Docente de tiempo completo en la Facultad de Lenguas, BUAP. México, Puebla. georgina.aguilar@correo.buap,mx ORCID: https://orcid.org/0000-0002-7639-9084
}

Artículo recibido: 4 de septiembre de 2018

Artículo aceptado para publicación: 23 de agosto de 2019

Ariza, Méndezy Aguilar doi: https://doi.org/10.36799/el.v4i2.100 Volumen 4, Número 2, Año 2019, ISSN: 2448-5942 
identify the tasks that accompany undergraduate thesis writing and (2) to explore how these tasks work towards building the academic text. Preliminary results corroborate that reading and research tasks are inherent to developing an academic text; therefore Reading, Writing, Research tasks (R-W-R tasks). However, the results suggest that the interrelation of these social practices is not evident while writing a thesis. Tasks may be regarded in isolation by both thesis writers and supervisors, which may prevent a successful completion of the written text. This segmented view also constrains the development of research literacy. This paper may have implications to make thesis supervision and writing more explicit.

KEY WORDS: literacy tasks, academic writing, research tasks, conceptual integration

\section{INTRODUCTION}

This paper starts from a genuine interest to address the struggles students go through in the endeavor of writing a thesis. Writing a thesis involves a number of intricate social processes whose interrelation constitute a genre system (Bazerman, 1994). Understanding this intricacy becomes a challenge for novice writers who have not experienced the genre before. For example, writing a research proposal, finding a supervisor and a committee and making an oral defense are all part of the thesis writing process (Autrey and Carter, 2015). However, the particularities of each social processes as well as its interrelation are often times occluded for the novice writers. We think that supervision is core to let students know what it takes to write a thesis and become research literate by means of setting effective tasks. In order to understand how this can be done, it is necessary first to understand what it means to be literate and how people become literate.

Gaining a comprehension of literacy is not straightforward since its meaning and the approaches to its study vary in "specific times and places and continually need to be reviewed and re-evaluated as cultures, societies and their literacy technologies change over time" (De Silva Joyce and Feez, 2016, 4). In its basic definition, literacy means to be able to read and write in at least one language. Reading and writing as represented in texts are goal oriented practices and purposeful to a variety of social contexts (Martin, 1997). The challenge for novice writers is to recognize how those contexts configure as to be able to participate legitimately in a community of practice. Such is the case of thesis writing in the field of English Language Teaching as we will explain further.

The concept of literacy has evolved over time and it means different things to different people. This section describes different views of literacy placed along a continuum that is representative of most literacy theoretical approaches. On one end, there is the view of literacy that regards writing as an ability easily transferable to diverse contexts. This view draws from 
cognitive theories. In the middle of the continuum, literacy is regarded as a socialization process i.e. novice writers have to apprentice the conventions of the mainstream community in order to gain membership. On the other end of the continuum, there is a view that literacy is socially constructed under situations of power relations. This last view takes into consideration issues of epistemology and identity (Lea and Street, 1998, 2). Lea and Street suggest that one view is not separated from the other. On the contrary, literacy as a social practice subsumes the socialization and the skills models $(1998,3)$. However, different views of writing carry on inherent pedagogies. For example, considering literacy as an ability may limit students understanding of the intrinsic social practices such as reading and writing. This creates a clash of what literacy involves for both thesis supervisors and thesis writers during the process of writing a thesis. Frequently, teachers who supervise students' work may not be able to clearly describe and set the tasks that allow students to become research literate as they read, write and carry out research. On their part, students tend to oversee writing; leaving aside the reading and research processes (Paltridge et al., 2009, 22).

In this paper, we try to move along the continuum on the view that sees literacy as a social practice. We agree with (Barton and Hamilton, 2010, 45) in that being literate is to be confident with one's own participation in literacy practices. In other words, we believe that students will succeed to the extent in which they have a firm grip of what literacy tasks imply. Thesis supervision may contribute to this endeavor by making research tasks as explicit as possible. The next section describes a review of studies in writing and supervision. It also takes the definition of literacy practices further to build up the concept of reading-writing-research (R-W-R) task.

\section{SUPERVISION AND THESIS WRITING}

Thesis writers at undergraduate level face a series of challenges. Fully processing and effectively using texts they read in the construction of the written text that is to be revised by a supervisor constitute one of the most crucial tasks. Teaching staff has reported that further and higher education students do not fully transit from processing course material to critically producing written material. Itua, Coffey, Merryweather, Norton and Foxcroft, for example,

Ariza, Méndezy Aguilar doi: https://doi.org/10.36799/el.v4i2.100 Volumen 4, Número 2, Año 2019, ISSN: 2448-5942 
explain that academic writing seems to be left underdeveloped throughout academic disciplines in higher education $(2014,307)$. In their study about perceptions and feelings about academic writing from both health students and lecturers, they set out to explore poor performance in academic writing on the part of first and second year university health students. Student participants indicated the need of more guidance, more teaching and more options available. However, they also acknowledged that more responsibility, resourcefulness and responsiveness on their part was necessary (Itua et al., 2014, 313). Similarly, teaching staff regretted not having asked students to go beyond their known limits, and to have reduced available readings to handout-like teaching materials for students' use. Some of these concessions, they also reported, have been a result of students who had jobs (Itua et al., 2014, 315). The academic staff felt they should have insisted more on students doing additional tasks such as using the library, engaging with the literature and processing journal articles under the supervision of teaching staff during lessons and courses (Itua et al., 2014, 316).

Similarly, in their study with five sociology students enrolled in an educational research course towards the end of their undergraduate program, González De La Torre, Jiménez Mora and Ignacio Rosas tried to determine whether their participants managed to fully comprehend and effectively use texts they read in the construction of their own written texts $(2016,11)$. These researchers argued that sociocultural conditions shape students' response to reading and writing practices. In addition, their analysis revealed that thesis supervision shapes what thesis writers do, in that their expectations and feedback directs thesis writers' actions and ways to proceed (González de la Torre et al., 2016, 15). In order to help in the thesis writing process Difabio De Anglat suggest that doctoral supervision in education in education should be able to assess the thesis writer's academic and research skills, model such skills for the thesis writer, set achievable expectations for the thesis writer, challenge the thesis writer within their own capacities during each tutoring session, channel and dose the amount and complexity of information the thesis writer receives, orient the design of the research project, lead regular high-quality sessions with the thesis writer, encourage frequent early writing tasks, and provide constructive feedback (2011, 938). Given that complexity, Wyatt and Pasamar Márquez emphasize the importance of modeling tasks for students, from finding appropriate online sources to designing data collection instruments and handling collected data $(2016,6)$. In addition, they note the usefulness of 
grouping students (e.g., according to their research interests) while also personalizing instruction and giving examples that would be particularly relevant to each student $(2016,8)$. Both these reading and writing practices constitute two of the literacy practices that we believe thesis writers should be able to participate in. The third of these practices is research practices, which may be perceived inaccurately by thesis writers.

There has been a growing interest to investigate how research is perceived, especially by novice researchers and by experienced researchers who supervise the first. Reyes-Cruz, Rueda de León-Barbosa and Murrieta-Loyo, for example, explore the research conceptions of 108 undergraduate pre-service EFL teachers at a public university in the southeast of Mexico (2017, 71). Their study considered the possibility of age and semester of instruction in their major having an influence in their research conceptions. In their study about how applied languages university students begin to engage in research in their field, Wyatt and Pasamar Márquez explored the benefits of guiding these first-year students in inquiry-based learning in an effort to make them see research as a stimulating, accessible activity $(2016,7)$. This study, which includes a 14-week introductory course on doing language research, presented the students' beliefs and understandings about research and the difficulties they perceived in actually carrying out small scale research $(2016,14)$. Both these studies inquire into how students in their early stages of development at their university programs perceive research. Nevertheless, while Reyes-Cruz et al. (2017) tried to determine whether students' conceptions became more sophisticated as they progressed in their studies, Wyatt et al. (2016) have their participants do research and inquire into their early research experience. In general, first-year students in Wyatt et al. did benefit from this highly structured exploratory course since they demonstrated methodological awareness that in some ways equaled that of last year peers $(2016,16)$. An unexpected finding in Undergraduate pre-service efl teachers' conceptions of research, however, is that 21-24 sixth semester preservice teachers obtained the highest misconception percentages as compared to their younger and older counterparts (Reyes-Cruz et al., 2017, 77). From these studies we can infer that it is of outmost importance that thesis writers learn about research, learn to do research, and learn to write about research in ways that are culturally accepted by those members of a research community, whose representative is the supervisor.

Ariza, Méndezy Aguilar doi: https://doi.org/10.36799/el.v4i2.100 Volumen 4, Número 2, Año 2019, ISSN: 2448-5942 
Supervision has been documented to be led by an expert in the field who can orient the thesis writer throughout the whole process. Nevertheless, as Difabio De Anglat emphasizes, supervisors do not simply carry out all previous tasks in a void. All these activities are aimed to promote the thesis writer's access to the culture of research into a very specific community of practice $-\mathrm{a}$ research community. Being able to interact with other academics and research students in the field in ways that are community-specific appropriate cannot easily be achieved by the thesis writer unless his/her and other supervisors create opportunities for thesis writers to benefit from interaction with other thesis writers, supervisors and experts in the field (2011, 944). These interactions usually occur in the shape of meetings with committees before whom thesis writers present their research project progress (Difabio De Anglat, 2011, 945). Therefore, gatekeeping the quality of the work produced by the thesis writer, Difabio De Anglat points out, is one of the two ends of a very delicate balance between support (as described in all instances where the supervisor assists and orients the thesis writer) and configuration (actions that place current academic standards on top of interest) at a postgraduate level of supervision $(2011,951)$. These studies seem to suggest that thesis writers do not have to wait until the end of their BA program to be involved in learning, doing and reporting about research, and that the earlier they start, the better.

The findings in Helping first-year undergraduates engage in language research by Wyatt et al. $(2011,2)$ are encouraging and add to the question of how early in their studies should be introduced to learning and doing research. Their study is similar to EFL undergraduate research courses, called research seminars, in that students are guided through writing about research. One outstanding difference, however, is that these research seminars in several EFL programs are usually offered in the last year of these programs. Since Wyatt et al. aimed to build confidence in these first year language students, working closely with each student and keeping a record of difficulties and frustrations they met was fundamental to scaffold instruction and guidance into learning research $(2011,9)$. The authors had not anticipated, for example, how intimidating it would be for their first-year participants to approach other individuals to collect data from them $(2011,12)$. In addition, Wyatt et al. report that first-year students who did not come to teaching sessions regularly showed limited research experience to interact with their participants and to treat them ethically and sensitively $(2011,13)$. Participants in their study, we could infer, may not

Ariz̧, Méndezy Aguilar doi: https://doi.org/10.36799/el.v4i2.100 Volumen 4, Número 2, Año 2019, ISSN: $2448-5942$ 
be old or mature enough to process what research entails and how research is reported in writing. Another possible scenario for students not fully comprehending what research implies could be not involving them in learning about or doing research on a regular basis. An unexpected finding in Undergraduate pre-service efl teachers' conceptions of research: A quantitative analysis by Reyes-Cruz et al., for example, is that 21-24 sixth semester pre-service teachers obtained the highest misconception percentages as compared to their younger and older counterparts (2017, 77). Reyes-Cruz et al. offered some possible reasons for this phenomenon. Their major, they explain, offered two research courses only, the first one in their first semester, and the second four years later in their tenth semester. This leaves sixth semester informants without formal opportunities to exercise their research skills, or to work on previously learned concepts. They also considered the fact that informants may not have too many teachers who could be doingresearch role models. However, the researchers also acknowledged that only the second tenthsemester research course is taught by EFL trained professors, while the first one is not $(2017,78)$.

An encouraging finding in Reyes-Cruz et al. $(2017,79)$ has to do with the fact that tenthsemester participants hesitate about the factor "research is finding the truth". Although this item could have caused some confusion among informants, the discussion about students evolving to more complex and sophisticated conceptions of research as they progress to more advanced semesters, as they advance in age and as they go through more learning experiences is opened. Conceptions about research, learning about research, doing research and learning to write about research all require processing texts to be read and processing texts to be written as one of the basic components of academic literacy for research purposes. González de la Torre et al., for example, claim that students' texts serve as a window into their reading practices and research capacities $(2016,4)$.

Participants in their study produced written texts as they followed instructions, given to them as a course assignment. The texts are analyzed to unveil participants' reading practices and level of complexity. On the one hand, González de la Torre et al. do find evidence of participants not showing full command of the ways in which the academic community they belong to interact with other communities through writing. An example of that is the apparent lack of familiarity with quoting and citing the sources they read in the texts that participants produce $(2016,5)$. Overall, participants' texts do not fully provide evidence of the most sophisticated reading level, 
a level when they achieve to interact with several same-topic/same-argument texts at a time. On the other hand, however, they do acknowledge that even when students have been taught when and how to proceed in specific ways, omissions and similar writing practices occur. An example of such student behavior is that one of their participants presented author's words verbatim in italics, but a page number is not indicated $(2016,12)$. These and other deficiencies revealed in their participants' written texts, González de la Torre et al. explain, can delay these students' full access and recognition as a rightful member of the academic community. In sum, studies highly focusing on the model of writing as a skill or mechanics, may not be so explicit about what reading and writing social practices implies to be academically literate $(2016,16)$.

\section{READING-WRITING-RESEARCH TASKS}

This review has showcased the difficulties in the supervision process because of the different expectations supervisors and writers have. That might also be related to the different conceptions that we have about research writing, particularly when accomplishing the tasks that are made to complete the thesis. Thus, theses and dissertations are the notable cases where many social processes intertwine towards the development of the written text. Its accomplishment requires not only being able to process texts to be read and written, but also to be critically evaluate literature, discriminate information and build their own text. Understanding tasks interacting discourses may enable novice writers to unveil the social practices involved in thesis writing. This, in turn, could open more opportunities for becoming research literate. The following sections describe the method to explore the nature of the reading-writing-research tasks.

\section{METHOD}

This study explored the tasks that students carried out in the process of writing a thesis. Particularly, it focused on the tasks that were assigned by supervisors in different stages of writing a thesis at an undergraduate English Language Teaching program in Central Mexico. The orientating questions are: What are the tasks that accompany thesis writing? How do these tasks work towards building the academic text? In order to address these questions, this paper aimed to identify the tasks that accompany undergraduate thesis writing and to explore how these tasks

Ariz̧, Méndezy Aguilar doi: https://doi.org/10.36799/el.v4i2.100 Volumen 4, Número 2, Año 2019, ISSN: $2448-5942$ 
work towards building the academic text. Due to the nature of the study, a qualitative approach was pursued as it evokes the exploration of the topic by taking into account participants' view in their natural setting (Creswell, 1998, 19). Case study was the type of inquiry selected to determine the procedures for data collection. A case study is an intensive study of an individual or group of individuals to generate a detailed and principled description involving multiple sources of information rich in context.

\section{CONTEXT}

This study was carried out in the School of Languages in a public university in Central Mexico where students major in English Language Teaching (ELT). In this context, the thesis is one of the ways to obtain that degree at the end of the program. However, writing a thesis is often regarded as a graduation requirement which represents full recognition from the institution to obtain a certificate rather than a way to learn and construct knowledge. As it has already been mentioned, students find this process difficult, and writing this thesis in English adds to this perceived difficulty. It is at the end of their ELT studies that students have to disentangle the complexities of the genre.

\section{PARTICIPANTS}

According to (Trowler, 2012), the configuration of the universities are multiple and dynamic, and these configurations can be observed from groups, sub groups, academies and departments within the university. In order to explore the tasks that accompany the thesis writing process, we tried to find a group of students whose experiences shed light on the everyday social practices of thesis writing and supervision. Therefore, a purposeful, criterion-based sampling was used to select participants (Dörnyei, 2007, 128). The main criteria to select participants was their experience in the thesis writing process, either by being enrolled in a research seminar or by currently writing their thesis. In order to allow for genuine participation, a writing workshop for the school community was offered. The purpose of the workshop was not only to collect data, but also to give back attendees some classes and counseling sessions (Kaplan-Weinger and Ullman, 2015, 186).

Ariza, Méndezy Aguilar doi: https://doi.org/10.36799/el.v4i2.100 Volumen 4, Número 2, Año 2019, ISSN: 2448-5942 
Twelve undergraduate students took the workshop and nine of those students decided to join the study. Participants were all Spanish speakers, three male and six female, mean age 23. Their English level according to their school records is close to B2. All of them were in the process of writing a thesis for one of the undergraduate ELT programs available in Central Mexico. Even though, they were in different stages of the theses writing process, the nine participants in this study had all completed a draft of their introductions and literature reviews. Five of them, had already completed chapters three and four of the thesis. The participants were informed about the procedures of the study and signed a consent letter. They were explained that a focus group would be recorded at the end of the workshop, and that they could withdraw at any time of the study.

\section{INSTRUMENT}

In this qualitative study, a focus group was carried out for the collection of data. The focus group allowed us to hear the true voices of participants and explore their experiences, opinions, wishes and concerns about the thesis writing process (Barbour and Kitzinger, 1999). The interaction within participants produces context-bound data and insights that would be less accessible by other means. A set of guiding questions about the process to write their thesis was used to conduct a focus group with all nine participants. The questions were related to the tasks they are asked to do when writing each chapter of the thesis.

\section{DATA COLLECTION AND ANALYSIS}

The focus group was carried out at the end of the workshop by one of the researchers in this study while the others were observing and taking notes. Interviewer-researcher had no student-teacher or student-supervisor connection with any of the six participants. This was important for the analysis stage. The data was tape-recorded, transcribed and theme analyzed. Theme analysis started with simultaneous and iterative coding; then theme building was constructed in two initial phases, individual and collaborative. Collaborative analysis required the use of layering, which led to the development of interrelating themes (Creswell, 2005, 237) that led researchers to revise data more critically.

Ariz̧, Méndezy Aguilar doi: https://doi.org/10.36799/el.v4i2.100 Volumen 4, Número 2, Año 2019, ISSN: $2448-5942$ 
As a first step, the three researchers conducted an independent analysis of the full transcriptions in order to identify salient themes or patterns (Wolcott, 1994, 142). Researchers then met to discuss these initial themes and recurrent patterns. It was noticed that participants referred to their research activity through a variety of tasks that were either self-assigned or assigned by their supervisors. As these tasks appeared to be grouped and overlapping at the same time, charts to attempt to classify these tasks were designed for researchers to use in a second independent analysis. The emergent categories under which tasks were to be placed were reading, writing and research, as figure one below shows.

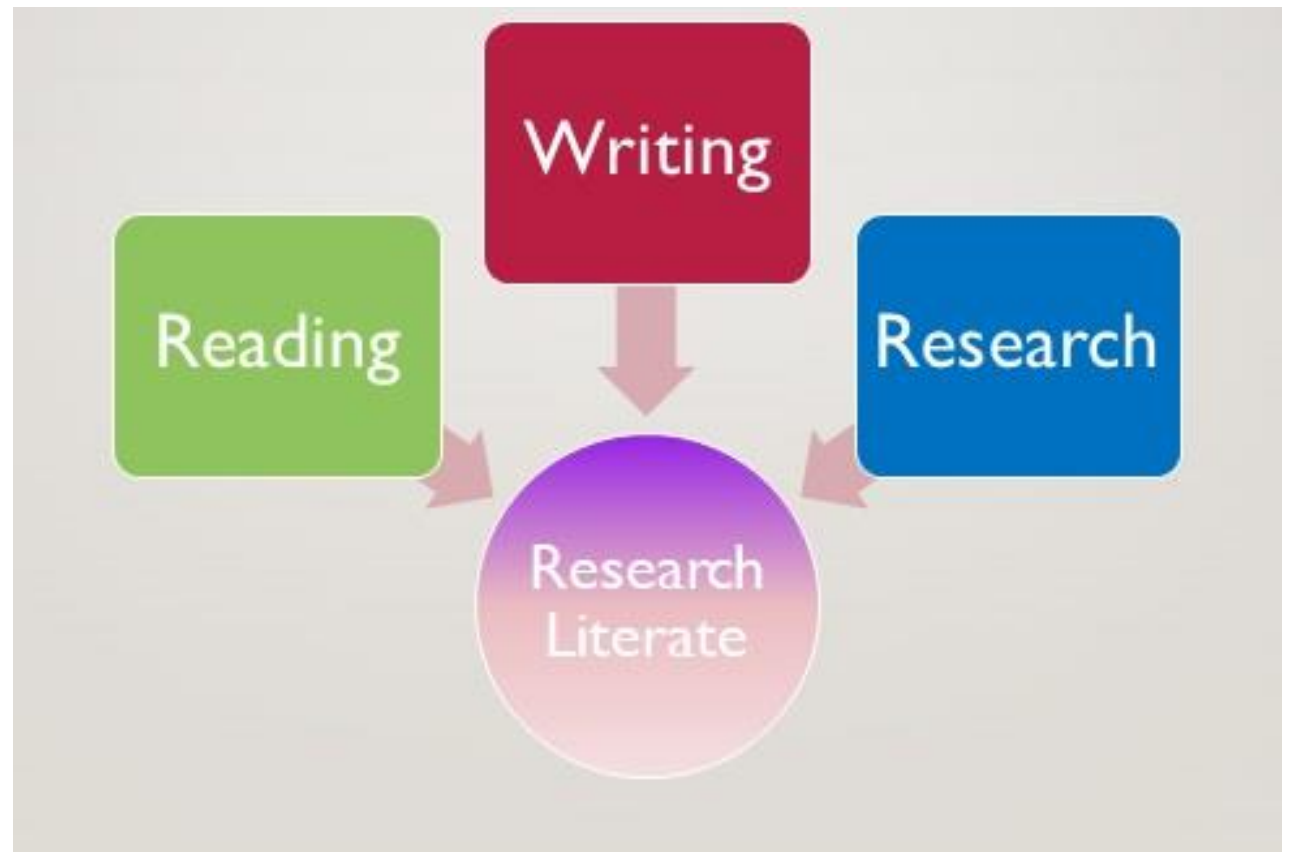

Figure 1: Becoming research literate at tertiary level

Data was to be labelled as tasks performed by thesis writers, and these tasks were to be categorized into reading, writing and research tasks, each one identified by different color codes in raw transcriptions. Each researcher filled in a table such as the one below to organize data in these three categories: 


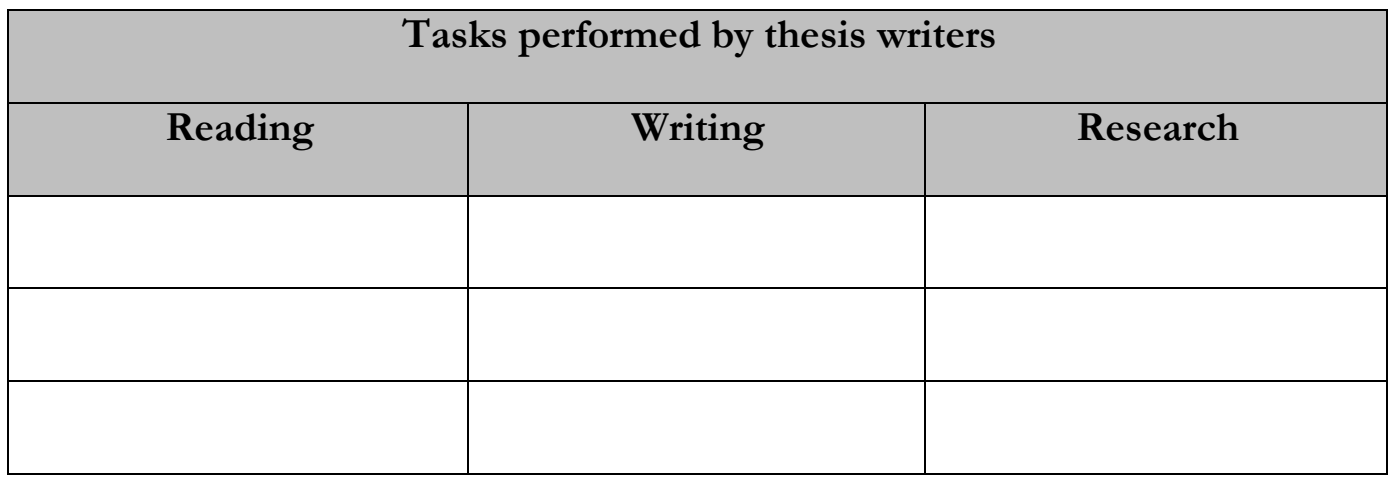

Table 1: Theme analysis chart to classify tasks

After individual analysis, all three researchers compared categories. It was realized that these were not clear cut, and that there were some overlapping categories. A task that was categorized as a reading task, for example, involved writing and researching activity, and several tasks categorized as writing were also relevant for the reading and/or researching label. In other words, the tasks worked in interaction and the three of them were necessary to accomplish a task for theses writing. This represented a challenge in the data analysis process; therefore, in order to sharpen the last categorization, it was decided that initial mentioning of reading, writing or research activity was to be taken into account. What participants would later explain after that first mentioning turned out to be extremely helpful to trace other tasks involved.

Researchers met again to reach a consensus on a final set of categories in a single chart. This final set of categories helped the researchers to identify four types of reading tasks, two types of writing tasks and two types of research tasks, as shown in Table 2 below. It is important to mention that even though they are categorized as one type of tasks, for instance, reading tasks, the other two types of tasks are often embedded as it will be explained further in the results section. 


\begin{tabular}{|l|c|l|}
\hline RWR tasks & $\begin{array}{c}\text { Types of } \\
\text { tasks }\end{array}$ & \\
\hline Reading tasks & 4 & Students are provided with specific texts to read \\
Students seemed to be asked to read books and research articles \\
Students are asked to read about their topic of interest \\
Students tend to read by using strategies that help to identify \\
moves in the texts
\end{tabular}

Table 2: Final set of categories

The results section below discusses the types of reading, writing and research tasks and how they intertwine. This overlapping categorization unveils some of the challenges involved in thesis writing.

\section{RESULTS}

Preliminary results provide evidence that literacy practices are not clear cut. Writing a thesis involves tasks inherent to developing an academic text that merge features of reading, writing and research henceforth R-W-R tasks. In this section, the way in which RWR tasks contribute or constrain to develop the academic text and enhance undergraduate students to become literate is discussed. 


\section{READINGS TASKS}

With respect to the reading tasks involved in thesis writing, it was found that reading appears to be the first step to follow when participants start to write their research topic for their thesis as one of the participants declares "(Teacher) recommends a lot to read, read, and read; then, based on what we have read, we identify the problem of the study ... reading has mainly been the tasks or activities that we have to do to be able to start writing" (P1). Thus, reading could be considered as the main source of input for students to clearly find out what they want to research about. This finding shows that for these participants and their teachers reading plays an important role in writing (Paltridge, 2009, 22). However, there is a case in which one participant reported that through the reading, she did not accomplish what she expected and she got dissatisfied with her research topic as stated in this quote "Once it was noticed that there wasn't enough information (inaudible), I ended up doing something else, so this was not pleasant for me; it wasn't satisfactory for me" (P7).

When being asked to read, thesis writers seem to be guided into what texts to read and how to approach them. For the former, it could be assumed that there is a tendency to use certain types of texts, which in this case are books and research articles as it could be seen in the following quotes: " a specific task was 'read these books' ”(P8). "It took me a week to read articles and books" (P5). For the latter, when students carried out their reading tasks, it was evident that they had already been provided with strategies that helped them through the reading process by identifying relevant information for their research as two of the participants claims:

... with these texts what we had to do was to read them, but not in a superficial way; we had to go deeper into the text and interpret the author's message, so we marked and underlined all those elements that excelled ... in a certain statement the author is presenting the problem or all this section is the introduction ... it was a lot of analysis (P5).

... we had to identify first the basic parts, which was the introduction of the topic, identify the objectives, problem and then the results and discussion; we also had to identify other parts of the discourse (P1).

Ariza, Méndezy Aguilar doi: https://doi.org/10.36799/el.v4i2.100 Volumen 4, Número 2, Año 2019, ISSN: 2448-5942 
Thus, time-consuming tasks as processing journal articles under the supervision of teaching staff during lessons (Itual et al., 2014, 316) was present to help students transit in their processing and understanding of written academic material. It is also relevant to emphasize that while participants were doing their reading tasks, they became aware about the importance of discriminating sources and applying reading strategies as it allows them to deeply and appropriately explore the texts as the following participant illustrates:

That is a problem because if a teacher only tells you 'read about the topic', 100 books, but if at the end you don't have strategies to identify and read, it will become a waste of time because you will only understand in a superficial way ... (P5).

Moreover, participants highlighted how analyzing the discourse as a reading strategy could have had an impact on their own writing of the thesis: "... that type of analysis...I mean, it is good because you will know about the writing of your own text” (P1).

When working on reading tasks, participants appear to possess useful strategies that they put into practice when they are working on their own. However, some of their choices seem more intuitive rather than supervisor-guided which makes them feel lost or frustrated while performing this task. Only one participant reported having received guidance to approach different types of texts to be read.

\section{WRITING TASKS}

When writing their thesis, participants reported they feel that they struggle with identifying and stating their research issue or problem. For instance, one of the participants admits his complication in establishing a research purpose: "The objective was a little difficult for me because there are different things in which I could focus on" (P1). Besides this, research possibilities seem to be numerous for participants, and deciding about which one to embrace is not without difficulties as declared by one of them "I changed many times the topic until I really decided about one” (P5). It was even found a case of a participant that was still unable to state his research questions: "I don't have my research questions up to now" (P1). All these situations

Ariz̧, Méndezy Aguilar doi: https://doi.org/10.36799/el.v4i2.100 Volumen 4, Número 2, Año 2019, ISSN: $2448-5942$ 
seem to hinder the development of the thesis project. Thus, other tasks and strategies should be provided besides the discourse analysis strategies when reading in order to appropriately equip students for writing their research issue/problem and avoid prolonged blocks that could lead to frustration.

Handing in thesis drafts for feedback and revision could be considered as another task that participants carry out. In this regard, students must provide a written product that requires an investment of time and effort as it involves reading, processing, understanding, organizing ideas and structuring them in a second language. Feedback and revision imply a "response to students' writing” (Reid, 1993, 205) and producing “changes on a piece of writing” (Wallace \& Hayes as cited in González Quintero and Roux Rodríguez, 2007, 55); thus, participants are required to recurrently reshape their ideas with the objective of improving their academic paper. Revision after feedback apparently is a difficult task to do for participants; they especially show resistance to change or eliminate some parts of what they have written as observed in the following quotes:

my hours of reading and writing were down (after getting teacher's feedback), but I always try to adapt what did not work in one part and try to put it in another place to compensate that part or my work, so it remains there (P1).

Regarding the findings on writing tasks, it could be assumed that participants mainly conceive writing as a product and they are not quite accustomed to experiences of writing as a process in which feedback and revision play an important role to improve. Furthermore, for participants, narrowing down their topic to write their research objectives and questions is a struggle that highly hinders their thesis writing process, so effective strategies should be proposed on this regard.

When reading and writing for the thesis, participants also work on research tasks. One highlighted research task commented by the participants was to look for other references that could contribute and enrich their research project on their own as one participant comments "What I did first was to look for all the possible sources" (P4). In this search, participants become immersed into academic conversations from which they start to participate mainly as spectators. It could be assumed that the more participants read, the more they are immersed and 
knowledgeable about the academic conversation around their research topic. Additionally, participants apparently become more selective in the material they read and start to identify the main exponents in their research field as illustrated by one participant:

... I revised one by one (the sources) and I discarded the ones that dealt with the same but perhaps took this trend ... it was a long process, as well as to read all of them, stopping to revise each of them to see what other new roads could be opened; maybe things I didn't know that were also applicable in this field I could also take that direction... also conferences in internet and TV interviews from some professors who are the leaders in the topic ... (P10).

Here, it was also found that during the searching process, participants tend to have difficulties to access certain sources as stated in the following quote: "It (the theme of the study) is widespread in Asia and ... more or less what I could, I found it because things (information sources) in Europe cost and you have to pay for them, or they are totally inaccessible" (P10).

Another evident research task reported by participants was citation. These participants tend to be asked to correctly cite the sources from which they are taking information to write their thesis, as well as to keep a record of them as one participant declares "I looked for the sources and I wrote the citations that seemed important to me ... it is relevant to consider all the books from where you are extracting (information) to cite them, as well as to make references appropriately" (P4). In this manner, it seems evident that participants are guided in developing commands such as quoting and citing that allow them to appropriately interact with their academic community through writing (González et al., 2016, 5) These kind of practices should be promoted as much as possible as they give thesis writers access to the culture of research.

As observed, the main research tasks in which students are involved are the searching of references and citation. As students work on these tasks, they tend to become more immersed in academic conversations and writing. In addition, students' voices begin to be heard in their thesis and they start to participate legitimately in their academic community of practice.

Ariza, Méndezy Aguilar doi: https://doi.org/10.36799/el.v4i2.100 Volumen 4, Número 2, Año 2019, ISSN: 2448-5942 


\section{RWR TASKS IN THESIS WRITING}

In the process of writing a thesis, participants do a variety of tasks. In this continuum, the task focus tends to vary according to the set objectives at different times. As seen in the findings, tasks do not occur in isolation; they overlap and nourish each other. Furthermore, when working on tasks, students tend to have periods of individual work as a participant reports "I have modified my introduction like five times because each time I find better ideas; I read it again and I say 'I don't like this too much', so I change it; I polish it more" (P5) and others of being accompanied by a supervisor as shown in this participant's quote: "My thesis supervisor questions me more what I write; I like that because s/he makes me reflect about what I do" (P8).

When doing RWR tasks, it seems advisable to provide opportunities for both types of work, individual work and supervisor-student dialogue. The first allows opportunities for reflection and internalization of thoughts and ideas. The second seems to have a higher impact on participants' work as they are usually questioned on what they write and how they express their ideas in their thesis as acknowledged by one of the participants “... but s/he questioned me a lot, 'I don't understand this, explain to me'. Then, I explained to s/he, but s/he said: 'You don't have that written"'(P5). As noticed, supervisor-student dialogue leads participants to a more reflective state in which they revise their texts by reformulating and transforming knowledge as a participant points out "Many of us came to reassess many things in the moment that we were questioned" (P4). This result concurs with González De la Torre et al.'s research with respect to thesis supervisors' influence on shaping what thesis writers do during the thesis writing process.Working under questioning style of supervision engages student in reframing what they will write about. However, setting clear expectations of the task, and offering informed guidance can facilitate the process of writing, which in turn, develops the academic text. The next section discusses the implications of these findings towards the development of research literacy.

\section{DISCUSSION}

The purpose of this research has been to explore the complexity of the thesis writing process -one which involves an interrelationship of different social practices-, and in doing so, reaching an understanding of some of the struggles students go through in the endeavor of

Ariza, Méndezy Aguilar doi: https://doi.org/10.36799/el.v4i2.100 Volumen 4, Número 2, Año 2019, ISSN: 2448-5942 
writing a thesis. In order to advance this comprehension, this paper attempted (1) to identify the tasks that accompany undergraduate thesis writing and (2) to explore how these tasks work towards building the academic text. Generally, we identified a classification of reading, writing and research tasks, which addressed the first question. However, while exploring how these tasks work toward building the academic text, it was found that they interact and overlap with each other as thesis writing progresses. This overlapping could probably explain why it could be sometimes complex for supervisors to deconstruct this process for thesis writers. In addition, thesis writers may feel that a given task is overwhelming because it does not point at a concrete product or step to follow, and ultimately, it does not make explicit the interrelation of reading, writing and research.

We believe that supervisors may be aware of what is involved in research and that they even push the thesis writers in that direction. However, these students seem to need more detailed instructions, scaffolding and reasons why they should proceed as they are told. Clearly, interaction with their supervisors does help thesis writers to see the end of a task, as well as the beginning of another. Thus, promoting opportunities for supervisor and thesis writer interaction providing constructive feedback while writing the thesis is quite helpful in raising writers' awareness of all the intricate social processes involved in this genre system.

This paper contributes in comprehending the nature of academic writing as a social practice that involves reading, writing and research. This view has some implications for supervision, students' learning and practical applications. For example, while in the process of the thesis writing and under supervision, students should be able to determine what is required of them in terms of RWR tasks. They should be aware of how long different tasks take or what they imply and realize how different tasks combine to develop an academic text. That could be done in face-to-face supervision sessions where thesis writers and supervisors meet to discuss thesis writing. This interaction may have to be agreed between supervisor and thesis writer, for instance, they could agree on 50-minute weekly sessions that both commit to. An issue that the present study unfortunately does not have information for is whether meeting frequently with their supervisors is perceived as being more helpful by thesis writers. Nevertheless, agreed sessions may be based on determining clear RWR tasks, the length of the assignment and the setting of achievable goals to successfully finish an assignment.

Ariza, Méndezy Aguilar doi: https://doi.org/10.36799/el.v4i2.100 Volumen 4, Número 2, Año 2019, ISSN: 2448-5942 
If supervision sessions are organized following these considerations, feelings of confusion or frustration experienced by thesis writers may be overcome by sense of achievement, self-awareness and pride. Such conditions could better advance BA in ELT thesis writers' understanding of the interactive and cyclical nature of reading, writing and research, which in turn can advance research literacy development.

We are aware that more research is still necessary to dilucidate, for example, specific tasks according to each of the thesis chapters, an informed pedagogy to teach them and the effect of those tasks in academic writing in English. However, understanding that, and understanding how reading, writing and research intertwine in the thesis writing process is a first step in trying to develop a better sense of what it means to become academically literate. Our study suggests starting points in which this can be done.

\section{REFERENCES}

Autrey, Meagan Kittle, and Michael Carter. "Unblocking occluded genres in graduate writing: thesis and dissertation support services at North Carolina State University." Composition Forum, 31 (2015). 2 September 2019. https:// files.eric.ed.gov/fulltext/EJ1061566.pdf

Barbour, Rosaline S. and Jenny Kitzinger. Developing focus group research: politics, theory and practice. London: SAGE publications, 1999.

Barton, David, Hamilton, Mary. "La littératie: une pratique sociale". Langage et société, 3(133) (2010): 45-62

Bazerman, Charles. "Systems of genre and the enactment of social intentions." In Freedman, Aviva and Peter Medway (Eds.). Genre and the new rhetoric. London: Taylor and Francis, 1994.

Creswell, John. Qualitative Inquiry and Research Design: Choosing among Five Traditions. California: SAGE Publications, 1998.

Creswell, John. Educational research: Planning, conducting and evaluating quantitative and qualitative research. New Jersey: Merrill Prentice Hall, 2005.

Ariza, Méndezy Aguilar doi: https://doi.org/10.36799/el.v4i2.100 Volumen 4, Número 2, Año 2019, ISSN: 2448-5942 
De Silva Joyce, Helen, and Susan Feez. Exploring literacies, theory, research and practice. UK: Palgrave McMillan, 2016.

Difabio De Anglat, Hilda. "Las funciones del tutor de la tesis doctoral en educación." Revista Mexicana de Investigación Educativa. 16.50 (2011): 935-59. 2 September 2019. https://www.comie.org.mx/revista/v2018/rmie/index.php/nrmie/article/view/400

Dörnyei, Zoltán. Research methods in applied linguistics. Oxford: Oxford University Press, 2007.

González De La Torre, Yolanda, José Jiménez Mora, and Jorge Ignacio Rosas. "Prácticas lectoras de estudiantes universitarios con fines de escritura académica." Revista Electrónica: Actualidades Investigativas en Educación. 16.1 (2016): 1-19. 2 September 2019. doi: http://dx.doi.org/10.15517/aie.v16i1.21971

González Quintero, Elsa Fernanda, and Ruth Roux Rodríguez. "The use of peer feedback in the English as a foreign language classroom: A case study.” Sintagma. 5 (2007): 54-68. 2 September 2019. https://sites.google.com/site/sintagmauaemex/5 4abs

Itua, Imose, Margaret Coffey, David Merryweather, Lin Norton and Angela Foxcroft, "Exploring barriers and solutions to academic writing: perspectives from students, higher education and further education tutors." Journal of Further and Higher Education. 38.3 (2014): 305-26. 2 September 2019. https://doi.org/10.1080/0309877X.2012.726966

Kaplan-Weinger, Judith, and Char Ullman. Methods for the ethnography of communication. Language use in schools and communities. New York: Routledge, 2015.

Lea, Mary R., and Brian V. Street. "Student writing in higher education: An academic literacies approach.” Studies in Higher Education 23.2 (1998): 157-72. 2 September 2019. https://doi.org/10.1080/03075079812331380364

Martin, James. "Analyzing genre: Functional parameters." Genre and institutions: Social processes in the workplace and school. London: Cassell, 1997.

Paltridge, Brian, Lesley Harbon, David Hirsh, Huizhong Shen, Marie Stevenson, Aek Phakiti and Lindy Woodrow. Teaching academic writing: An introduction for teachers of second language writers. Michigan Teacher Training. Ann Arbor: University of Michigan Press, 2009. 
Reid, Joy M. Teaching ESL writing. New Jersey: Prentice Hall, 1993.

Reyes-Cruz, María del Rosario, Lorgia Isamar Rueda de León-Barbosa, and Griselda MurrietaLoyo. 'Undergraduate pre-service efl teachers' conceptions of research: A quantitative analysis." Colombian Applied Linguistics Journal. 19.1 (2017): 67-83. 2 September 2019. doi: https://doi.org/10.14483/calj.v19n1.10534

Trowler, Paul. Universities into the 21st century. Cultures and change in higher educaction. New York: Palgrave MacMillan, 2008.

Wolcott, Harry. Transforming qualitative data: description, analysis and interpretation. Thousand Oaks, CA: Sage, 1994.

Wyatt, Mark, and Carmen Pasamar Márquez. "Helping first-year undergraduates engage in language research.” Language Teaching Research. 20.2 (2016): 146-64. 2 September 2019. doi: https://doi.org/10.1177/1362168814562013

\section{APPENDIX A}

Instrument: Focus group interview protocol

1. ¿Qué tareas o actividades te han sido asignadas por tu director durante el proceso de la escritura de tu tesis?

2. ¿Cómo las llevas a cabo?

3. ¿Cuánto tiempo te tardas en completar la actividad que tu director te ha pedido realizar?

4. ¿Cómo es la entrega de la tarea? ¿Cómo es el feedback recibido? ¿Te vuelven a asignar tarea?

5. ¿En qué tiempo regresas a tu siguiente revisión?

6. ¿Cómo te preparas para tu siguiente revisión?

7. ¿Cómo te sientes, de acuerdo al tipo de feedback que tu supervisor te brinda? ¿Qué tan efectivo es?

Ariz̧, Méndezy Aguilar doi: https://doi.org/10.36799/el.v4i2.100 Volumen 4, Número 2, Año 2019, ISSN: $2448-5942$ 
8. ¿Qué tareas o estrategias has hecho por tu cuenta para avanzar en el capítulo uno?

9. ¿Qué tareas o estrategias realizas para avanzar en cada uno de los capítulos?

10. Finalmente, ¿cuánto tiempo te ha tomado para lograr el avance de los capítulos de tu tesis Hasta el momento? 